\title{
Moss mites (Acari: Oribatida) in soil revitalizing: a chance for practical application in silviculture
}

\author{
ANDRZEJ KLIMEK ${ }^{1}$ and STANISŁAW ROLBIECKI ${ }^{2}$ \\ ${ }^{1}$ Department of Zoology and Landscaping, UTP University of Science and Technology, \\ Kordeckiego 20, 85-225 Bydgoszcz, Poland \\ ${ }^{2}$ Department of Land Melioration and Agrometeorology, UTP University of Science and Technology, \\ Bernardyńska 6, 85-856 Bydgoszcz, Poland
}

Corresponding author: Andrzej Klimek, e-mail: klimek@utp.edu.pl

(Received on 30 June 2014; Accepted on 11 June 2015)

\begin{abstract}
The Oribatida (known as moss mites or beetle mites) increase the breakdown of organic material in the soil. The paper analyses the dynamics of their abundance and number of species after various treatments enriching the soil in 4 study areas: afforested post-agricultural area in the Tuchola Forest, afforested degraded post-military training area in Bydgoszcz-Jachcice, and forest nurseries at Białe Błota and Bielawy. The results show that in post-agricultural and degraded soils at the initial stages of forest succession, the density and number of species of oribatid mites were low, even after phyto-land-improvement (afforestation and lupin as green manure). In the forest nurseries, however, we recorded a positive effect of soil revitalizing after mulching with forest ectohumus (i.e. organic surface layer of the soil). The inoculation of soils with forest mesofauna appeared more effective in nursery plantations of silver birch (Betula pendula) and small-leaved lime (Tilia cordata), as compared with Scots pine (Pinus sylvestris). Thus to revitalize degraded soils effectively and to accelerate forest succession, apart from phytoland-improvement, it is advisable also to reintroduce mesofauna, e.g. with the use of forest ectohumus.
\end{abstract}

Keywords: post-agricultural area, degraded soil, soil revitalizing, bioindication, reintroduction, oribatid mites

\section{INTRODUCTION}

Small soil animals affect many processes taking place in soil and their presence mostly positively affects its fertility and productivity. Thus mesofauna may intensify the soil processes and revitalize degraded soils. The soil fauna can be used in the processes of revitalizing soils in 2 ways: as soil health bioindicators or as soil supplements, because the introduction of mesofauna can speed up soil metabolism (HAIMI 2000). The restoration of soil fauna usually also takes place in 2 ways: by improving the life conditions (stimulation of native populations) as well as soil inoculation: introducing species potentially beneficial for us. 
In soil environments, mites (Acari) are mostly dominated by oribatid mites (Oribatida), which have a positive effect on the formation and maintenance of proper soil structure, the spread of bacteria and fungi, and indirectly on the formation of endo- and ectomycorrhizae (Klironomos \& Kendrick 1996; Behan-Pelletier 1999; SCHNEIDER et al. 2005; REMÉn et al. 2010).

In our long-term research, we analysed the occurrence of oribatid mites, to evaluate effects of soil revitalizing treatments in various conditions: phyto-land-improvement by means of afforestation and/or organic fertilization (lupin as green manure), and reintroduction of the edaphon (soil organisms). The treatments were performed in soils that were formerly degraded or used for agriculture and in forest nurseries. The aim of this paper is to show the influence of various treatments on communities of oribatid mites (in respect of the density of mites and number of species) in 4 areas: afforested post-agricultural area in the Tuchola Forest, afforested degraded post-military training area in Bydgoszcz-Jachcice, and forest nurseries at Białe Błota and Bielawy.

\section{MATERIAL AND METHODS}

\section{Post-agricultural area, Linówek, Tuchola Forest (5343'41.7'”N, 18¹4'03.9”'E)}

Field research was performed in 2006 and 2009 in young forest stands of Scots pine (Pinus sylvestris L., 1753) and silver birch (Betula pendula Roth, 1788) on a fresh (i.e. moderately moist) coniferous forest site (Bśw according to the Polish classification of forest sites), planted in 2001 in a post-agricultural area. In 2009 the forest stands, having achieved full crown closure, were at the early stage of young tree. More information on the research area can be found in papers published earlier: KlimeK \& Pokora (2009), KlimeK \& Kowalska (2013).

\section{Degraded area, Bydgoszcz-Jachcice (5308'45.0”'N, 1758'57.0”'E)}

Research was performed in 2008-2009 in a post-military training area in Bydgoszcz-Jachcice, after its afforestation with Scots pine. Pine was planted there in the spring of 2008 on a fresh pine forest site (Bśw according to the Polish classification). We analysed 2 variants of the experiment: plots with lupin (Lupinus luteus L., 1753) as green manure (grown in 2007) and without that treatment. A detailed description of the experiment is provided by KLIMEK et al. (2009a), KLIMEK \& ROLBIECKI (2011).

Forest nursery, Białe Błota, Bydgoszcz Forest District (5306'11.4 'N, 17055 '41.4'”E)

In 2008-2009 we performed research it the forest nursery at Białe Błota near Bydgoszcz, in plantations of Scots pine and small-leaved lime (Tilia cordata Mill., 1768). The experimental factor was mulching with forest ectohumus (i.e. organic surface layer of the soil) derived from a fresh forest site (Bśw according to the Polish classification). The seeds were sown in late April 2008. Mulching with fresh ectohumus was performed in mid-September 2008. It was applied at a rate of $100 \mathrm{~m}^{3} \cdot \mathrm{ha}^{-1}$, and mixed with the soil layer down to about $1-2 \mathrm{~cm}$ deep. The plants were irrigated with a stationary sprinklers, following the guidelines developed for forest nurseries. The irrigation pattern, weather conditions as well as soil characteristics were described in earlier publications (KLIMEK et al. 2011; RoLBIECKI et al. 2013). 
Forest nursery, Bielawy, Dobrzejewice Forest District $\left(53^{\circ} 01^{\prime} 35.4^{\prime \prime} \mathrm{N}, 18^{\circ} 43^{\prime} 03.0^{\prime \prime} \mathrm{E}\right)$

The experiment was performed in 2008-2009 at the forest nursery Bielawy near Torun in the nursery plantations of Scots pine and silver birch. The seeds were sown in late April 2008. Mulching with forest ectohumus derived from a fresh forest site (Bśw according to the Polish classification) was performed in mid-September 2008. It was applied at a rate of $100 \mathrm{~m}^{3} \cdot \mathrm{ha}^{-1}$, placed between rows of seedlings and then mixed with top soil (about $1-2 \mathrm{~cm}$ deep). The plants were irrigated with a stationary sprinkler, following the guidelines developed for forest nurseries. The irrigation pattern, weather conditions, and soil characteristics were given in earlier publications (RoLBIECKI et al. 2009; 2010a, b; 2011).

\section{Sampling and observation of oribatid mites}

Some of the mite research results used in this study were published earlier by KlimeK \& Kowalska (2013), KlimeK \& Pokora (2009), KlimeK \& Rolbiecki (2011), KLIMEK et al. (2009a; 2011), RoLBIECKI et al. 2009; 2010a, b; 2011; 2013). To make the results from different experiments comparable in that paper, we analysed a 2-year research cycle, 2 sampling dates (spring \& autumn) as well as selected factors of more thorough research. The samples for mite research were taken from an area of $17 \mathrm{~cm}^{2}$ to the depth of $3 \mathrm{~cm}$, in 10 replicates. Mites were extracted from the soil for 7 days using the modified Tullgren extractor. Next, they were preserved in ethanol and prepared. Oribatid mites were identified to the species or genus level, including juvenile stages. A total of 2671 oribatid mites were identified, including 52 species.

The mean density $(N)$ of Oribatida per $1 \mathrm{~m}^{2}$ of soil was calculated, and their species richness was expressed as the mean number of species/sample $(s)$. Numerical data prior to the statistical analysis were subjected to logarithmic transformation - $\ln$ $(x+1)$ (Berthet \& Gerard 1965). The statistical analysis was performed with Statistica 10.0 package. Normality was verified with the Kolmogorov-Smirnov test. Their distribution was not normal, so we performed a non-parametric analysis of variance (ANOVA: Kruskal-Wallis test), and in the case of significant differences $(P<0.05)$, also a post-hoc analysis for each pair (the Dunn's $z$ test), to select significantly different means.

\section{RESULTS}

\section{Post-agricultural area, Linówek}

In Poland, on poor sites in post-agricultural landscapes but also on forest soils, Scots pine is mostly planted and additionally silver birch is introduced. These species show different rates of growth - birch grows faster, producing shade to soil and in autumn producing abundant litter. Introduction of birch on post-agricultural land can be thus treated as a method of phyto-land-improvement.

The mean density of oribatid mites in the young pine stand was 7740 individuals $/ \mathrm{m}^{2}$ (Fig. 1). In the soil under the forest stand of silver birch it was lower and the differences between pine and birch were significant (ANOVA: $H=13.39, P=$ 0.0003; $z$ test: $z=3.60, P=0.0003$ ). Similarly, in the case of mean number of species $(s)$, a higher richness of Oribatida was found under pine than under birch (ANOVA: 


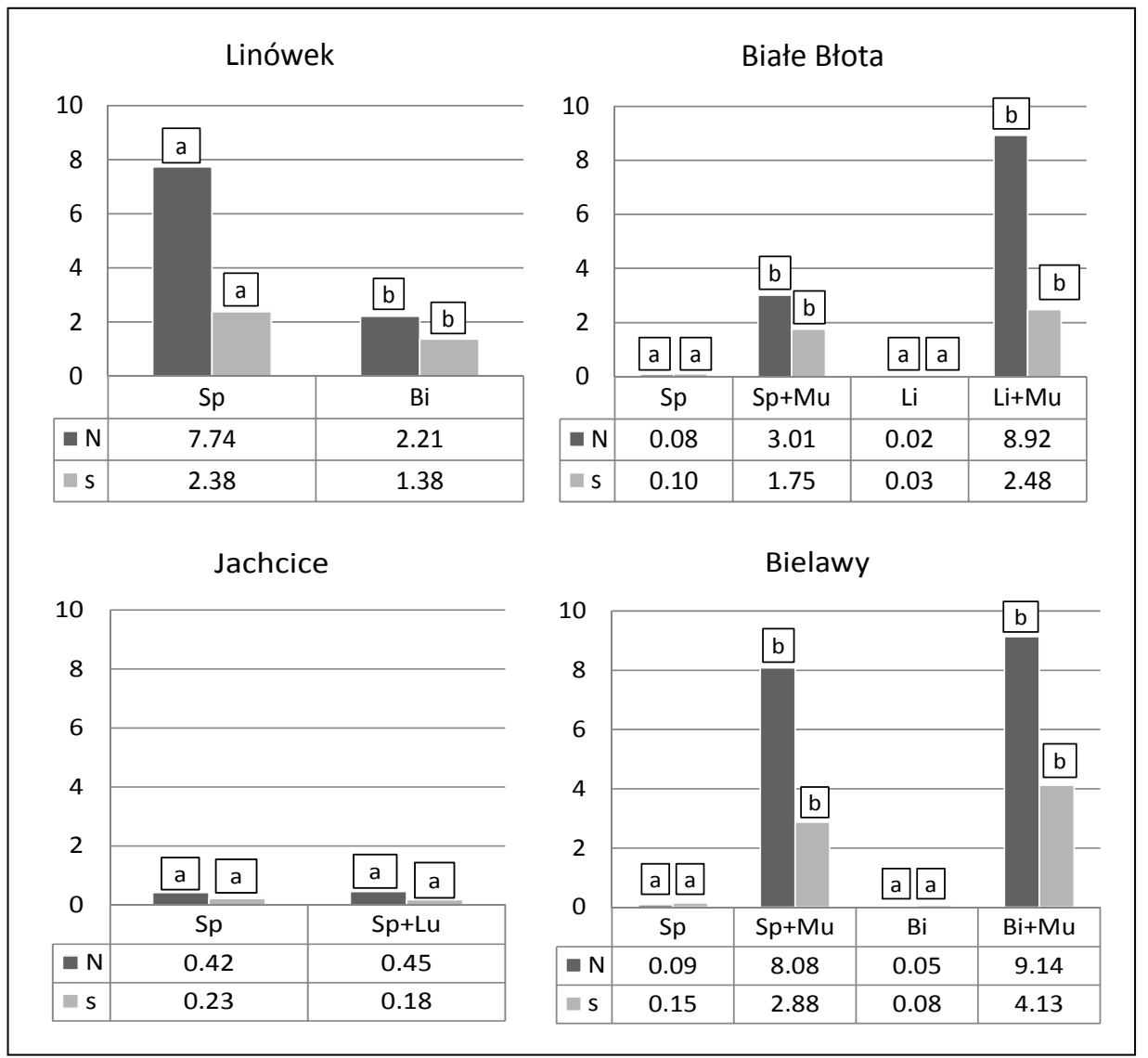

Fig. 1. Mean density of Oribatida ( $N$ in $10^{3}$ individuals $\left./ \mathrm{m}^{2}\right)$ and mean number of species per sample $(s)$ in the studied variants $(\mathrm{Sp}=$ Scots pine; $\mathrm{Bi}=$ birch; $\mathrm{Li}=$ lime; $\mathrm{Lu}=$ lupine; $\mathrm{Mu}=$ mulch; $\mathrm{a}, \mathrm{b}=$ the same letters denote non-significant differences, post hoc Dunn's $z$ test, $P<0.05$ ) in 4 study areas

$H=6.35, P=0.0117 ; z$ test: $z=2.46, P=0.0137)$. On successive sampling dates (spring of 2006 to autumn of 2009), the density and species richness of oribatid mites was always higher under pine than under birch (Table 1). Both the oribatid mite species abundance and their richness from the spring of 2006 to the spring of 2009 remained low. A many-fold increase in the values of both indices was noted only on the last date of research, in the autumn of 2009.

\section{Degraded area, Bydgoszcz-Jachcice}

Phyto-land-improvement treatments are applied in practice for the revitalizing and restoration of degraded post-agricultural soils allocated to afforestation. Such 
treatments include sowing sweet lupin as green manure a year before establishing a forest plantation. The treatment aims at improving the bioactivity of soils. Performed in the Bydgoszcz-Jachcice post-military training area, the treatment with lupin before starting a forest plantation increased neither the oribatid mites abundance nor the oribatid mites species richness (Fig. 1). In this area those mites occurred sporadically from the spring of 2008 to the spring of 2009. Slightly more abundant occurrence of oribatid mites was noted only on the last research date: 1510-1690 individuals $/ \mathrm{m}^{2}$ in the autumn of 2009 (Table 1).

Table 1. Seasonal dynamics of Oribatida $\left(N\right.$, in $10^{3}$ individuals $\left./ \mathrm{m}^{2}\right)$ and mean number of species per sample $(s)$ in the studied variants of experiments in the 2-year research cycle

\begin{tabular}{|c|c|c|c|c|c|c|}
\hline \multirow[t]{2}{*}{ Study area } & \multirow{2}{*}{$\begin{array}{c}\text { Experimental } \\
\text { variant }\end{array}$} & \multirow[t]{2}{*}{ Index } & \multicolumn{2}{|c|}{ First year } & \multicolumn{2}{|c|}{ Second year } \\
\hline & & & spring & autumn & spring & autumn \\
\hline \multirow{4}{*}{ Linówek } & \multirow{2}{*}{ pine } & $N$ & 5.60 & 4.76 & 3.73 & 16.86 \\
\hline & & $s$ & 1.20 & 2.20 & 1.60 & 4.50 \\
\hline & \multirow{2}{*}{ birch } & $N$ & 0.54 & 1.57 & 0.36 & 6.38 \\
\hline & & $s$ & 0.80 & 1.70 & 0.50 & 2.50 \\
\hline \multirow{4}{*}{ Jachcice } & \multirow{2}{*}{ pine } & $N$ & 0.00 & 0.12 & 0.06 & 1.51 \\
\hline & & $s$ & 0.00 & 0.10 & 0.10 & 0.70 \\
\hline & \multirow{2}{*}{ pine + lupine } & $N$ & 0.12 & 0.00 & 0.00 & 1.69 \\
\hline & & $s$ & 0.10 & 0.00 & 0.00 & 0.60 \\
\hline \multirow{8}{*}{ Białe Błota } & \multirow{2}{*}{ pine } & $N$ & 0.06 & 0.06 & 0.06 & 0.12 \\
\hline & & $s$ & 0.10 & 0.00 & 0.10 & 0.20 \\
\hline & \multirow{2}{*}{ pine + mulch } & $N$ & 0.00 & 7.34 & 2.83 & 1.87 \\
\hline & & $s$ & 0.00 & 3.90 & 2.00 & 1.10 \\
\hline & \multirow{2}{*}{ lime } & $N$ & 0.00 & 0.06 & 0.00 & 0.00 \\
\hline & & $s$ & 0.00 & 0.10 & 0.00 & 0.00 \\
\hline & \multirow{2}{*}{ lime + mulch } & $N$ & 0.06 & 10.29 & 8.13 & 17.22 \\
\hline & & $s$ & 0.10 & 5.70 & 2.60 & 1.50 \\
\hline \multirow{8}{*}{ Bielawy } & \multirow{2}{*}{ pine } & $N$ & 0.06 & 0.24 & 0.00 & 0.06 \\
\hline & & $s$ & 0.10 & 0.40 & 0.00 & 0.10 \\
\hline & \multirow{2}{*}{ pine + mulch } & $N$ & 0.00 & 27.57 & 0.24 & 4.52 \\
\hline & & $s$ & 0.00 & 9.80 & 0.30 & 1.40 \\
\hline & \multirow{2}{*}{ birch } & $N$ & 0.00 & 0.06 & 0.06 & 0.06 \\
\hline & & $s$ & 0.00 & 0.10 & 0.10 & 0.10 \\
\hline & \multirow{2}{*}{ birch + mulch } & $N$ & 0.00 & 24.86 & 2.59 & 9.09 \\
\hline & & $s$ & 0.00 & 10.00 & 2.10 & 4.40 \\
\hline
\end{tabular}




\section{Biate Błota forest nursery}

The conditions of growth of young trees in forest nurseries differ considerably from the conditions typical for them in forest ecosystems. As a result of frequent agrotechnical treatments and intensive production of the seedlings, the nursery soils are degraded. The biological conditions of soils can be improved by enriching the nursery with organic matter, e.g. by fertilizing it with composts or inoculating with edaphon, including the soil fauna derived from forest soil (e.g. by mulching). In the Białe Błota nursery, non-mulched plantations of pine and lime showed exceptionally low abundance and species richness of oribatid mites (Fig. 1). During the 2-year research cycle (2008-2009), the values of both indices remained low (Table 1), unlike in the stands where in September of 2008 mulching was made with forest ectohumus. Under pine in the autumn of the first study year, the density of Oribatida increased after mulching to 7340 individuals $/ \mathrm{m}^{2}$. In that case, however, the soil inoculation with mesofauna can be considered moderately successful, since the abundance of oribatid mites on successive sampling dates gradually decreased. Similarly, the number of species $(s)$ right after mulching was high (3.9), but later it decreased to only 1.4 species/sample at the end of the cycle.

Better results of the treatment were reported in the nursery plantation of lime. In the autumn of 2008, indices $N$ and $s$ were high (even higher than in pine plantations): 10290 individuals $/ \mathrm{m}^{2}$ and 5.70 species/sample, respectively. Although the species richness on successive sampling dates decreased, the density of oribatid mites in the autumn of 2009 increased considerably, to 17220 individuals $/ \mathrm{m}^{2}$.

\section{Bielawy forest nursery}

The experimental design in the Bielawy forest nursery was similar to the one described in the Białe Błota forest nursery, but beside the nursery plantation of pine, we investigated also the soil mite fauna of a silver birch plantation. Birch grows faster than pine, providing shade to soil and organic matter in autumn in the form of abundant leaf litter. However, during the entire 2-year research cycle the occurrence of oribatid mites in the non-mulched stands of both species was sporadic: 60-240 individuals $/ \mathrm{m}^{2}$ and $0.1-0.4$ species/sample (Table 1 ). In contrast, after the mulching with ectohumus, the maximum values of both indices were noted in the autumn of 2008, but in the spring of 2009 the numbers dropped remarkably and during the second growing season they increased. It is noteworthy that the decrease in oribatid mite abundance and species richness in the spring of 2009 under birch was milder than under pine, and the values of those indices at the end of the research period were clearly higher under birch. The 2-year mean values of $N$ and $s$ differed significantly between the mulched and non-mulched stands, both for pine (ANOVA: $H=15.86, P=0.0001 ; z$ test: $z=3.34, P=0.0008$; and ANOVA: $H=15.61$, $P=0.0001 ; z$ test: $z=3.31, P=0.0009$; respectively) and for birch (ANOVA: $H=34.04, P=0.0000 ; z$ test: $z=5.11, P=0.0000$; and ANOVA: $H=34.05$, $P=0.0000 ; z$ test: $z=5.11, P=0.0000$; respectively) (Fig. 1). 


\section{DISCUSSION}

In forest soils, oribatid mites are some of the most important representatives of the mesofauna; their presence determines the adequate functioning of the entire forest ecosystem. Those Acari, besides participation in organic matter decomposition, are stimulants and vectors of many microorganisms essential for the forest economy, e.g. mycorrhizal and saprotrophic fungi (SETALA 1995; RENKER et al. 2005). Soil animals feeding on fungi stimulate their growth (HANLON \& ANDERSON 1980) and when migrating they can inoculate the substrate with spores of fungi and hyphae (LussENHOP 1992; RENKER et al. 2005).

This study shows that in the post-agricultural and degraded soils at the initial stages of forest succession the abundance and richness of oribatid mites are very low. The phyto-land-improvement in the degraded post-military training area and post-agricultural land did not give the expected effect of increased biodiversity. In the post-military training area in the first 2 years after the afforestation and treatment with lupin, the density of oribatid mites was extremely low (120-1690 individuals $/ \mathrm{m}^{2}$ ). In comparison, in forest soil in a 2-year-old pine plantation set up after the forest stand was cut down, the density of those Acari was about 8180 individuals $/ \mathrm{m}^{2}$ (KLIMEK \& RolBIECKi 2011). In the post-agricultural area in the Tuchola Forest, both in birch and pine plantations, 5 years after the afforestation the density and species richness of oribatid mites were 2-fold lower than in a forest area after restoration of the forest stand (KLIMEK \& KOWALSKA 2013). Eight years after the establishment of forest plantations those disproportions in birch plantations were even greater. The acarological research performed in degraded and post-agricultural soils demonstrates that the succession of oribatid mites in those areas was much slower than in forest soils once the forest stand was cut down. It seems that to solve that problem, soils can be inoculated with living edaphon by using forest ectohumus in which soil mesofauna is very abundant.

In 2003-2004 in the Białe Błota forest nursery, we made the first attempts at inoculating the soil with the edaphon, with the use of forest ectohumus derived from an adult pine stand (KLIMEK et al. 2013a). The treatment was more effective in the nursery plantation of birch, as compared with pine. Our research team also found a positive effect of irrigation on the abundance and species richness of oribatid mites in birch and pine plantations (KLIMEK et al. 2008; 2009b; 2013a).

A favourable effect of birch on soil inoculation with edaphon was also noted in the experiment performed in 2008-2009 in the Bielawy nursery (RoLBIECKI et al. 2009; 2010a, b; 2011). The values of the indices analysed ( $N$ and $s$ ) on the last research date were higher under birch than under pine (Table 1). The high abundance and species richness of oribatid mites in the birch plantation indicate a positive effect of this tree species on the biological activity of soils. This observation can be important for nursery practice, especially facing the need for soil revitalizing in degraded forest nurseries.

In a similar experiment performed in the same years in the nursery plantations of pine and small-leaved lime in the Białe Błota nursery, we also noted a positive effect of soil inoculation with edaphon on seedlings of deciduous tree species. However, 
the species richness of oribatid mites some time after mulching in pine and in lime plantations usually decreased. The density of oribatid mites in the lime plantation in the autumn of 2009 was maximum, while in the pine plantation on the same date it was several-fold lower (Table 1).

The effect of oribatid mites on the quality of the production in forest nurseries is obviously indirect; it mostly involves increasing the activity of soil microflora (WALLWORK 1983) and accelerating organic matter decomposition processes by breaking it down into smaller particles. Oribatids, through a continuous reduction of the populations of bacteria and fungi, keep them at the growth stage (the so-called compensation growth). Some researchers claim that oribatid mites feed mostly on mycelium (LINDBERG \& BENGTSSON 2005), and the environmental conditions enhancing mycelium growth also have a positive effect on their populations (BLAKLEY et al. 2002; Pollierer et al. 2007), which additionally justifies their use as bioindicators of soil revitalizing.

The analysis of the occurrence of oribatid mites in afforested post-agricultural and degraded areas presented here points to a low biological activity of soils at the beginning of forest succession in those areas, even after phyto-land-improvement treatments. Literature on this subject shows that in raw soils, with difficult conditions for small arthropods, soil colonization by mites is rather slow and can take many months or even years (BECKMANN 1988; WANNER \& Dunger 2002; LeHMitz et al. 2011; KLIMEK et al. 2013a). LeHMitz et al. (2012) claim that active migration plays an important role in the colonization of this type of soils and various species of oribatid mites can use various modes of dispersal. However, only $35 \%$ of oribatid mites spread by underground migration, while $65 \%$ by overground migration. Passive migration paths, e.g. with the wind, are also possible (LEHMITZ et al. 2011).

SzUJECKI (1996) claims that the the set of soil fauna characteristic for forest soils is formed as late as 20-45 years after afforestation of agricultural soils. With that in mind, most afforestations should occur in an active restitution system, preceded by the introduction of organic matter with retention properties. With that in mind, MAZUR \& TRACZ (1996) suggest the recovery of the proper structure of soil fauna in post-agricultural land by treatments stimulating the populations that already exist in a given area and by reintroduction of the desired species. Those authors claim that an additional aspect of such activities can be an activation of microorganisms antagonistic to Heterobasidion annosum (Fr.) Bref., 1888, the main agent of root rot, which is a big problem in post-agricultural areas.

For many years we have made more or less successful attempts at inoculating soils with mesofauna, with the use of forest ectohumus and mulching of the soil surface (KLIMEK et al. 2008; 2009b; 2012; 2013a). The observations show that a lower effectiveness of that treatment can be due to excessive drying of the soil surface. The sensitivity of soil mesofauna, especially the Oribatida, to low moisture has already been reported (e.g. LINDBERG \& BENGTSSON 2005). In forest nurseries, in case of a lack of natural precipitation, irrigation is applied. In the post-agricultural and degraded areas, in general, there are no such possibilities and initial soils are deprived of the protective layer of ectohumus. With that in mind, one shall search for methods of water retention in soil over the periods of its deficits in the environment. It seems 
that a good idea to solve that problem is the application of mulching, preferably using the materials natural for forest ecosystems, such as wood waste remaining after logging. The resultant woodchips are a natural material used for orchard mulching, enhancing the soil microclimate properties, especially moisture (TREDER et al. 2009). It turned out that in woodchips used for the mulching of non-irrigated strawberry in a 2-year experiment cycle, a very rich Acari fauna developed, especially oribatid mites (KLIMEK et al. 2014). In the post-military training area exposed to revitalizing in Bydgoszcz-Jachcice, in the autumn of 2012 we set up an experiment in the pine plantation with the application of mulching with woodchips inoculated with edaphon from forest ectohumus. Preliminary observations of the samples with mites collected in 2013 are optimistic and show a chance of obtaining good results of reintroduction of soil mesofauna.

There is also a possibility of using the container nursery production to inoculate the soils with mites. It turned out that in small root clumps of the seedlings produced with the so-called covered root system, very abundant oribatid mites can live (KLIMEK 2013). Especially favourable conditions for the development of oribatid mites occur in small root clumps of deciduous species: small-leaved lime and silver birch. In 2013, the first attempt was made to introduce edaphon to some root clumps of pine (KLIMEK et al. 2013b). The experiment, however, turned out moderately successful, so further research is necessary to investigate the possibilities of restitution of soil mesofauna with small root clumps of tree seedlings.

\section{REFERENCES}

BeCKMAnN M. 1988. Die Entwicklung der Bodenmesofauna eines Ruderal Ökosystems und ihre Beeinflussung durch Rekultivierung: 1. Oribatiden. Pedobiologia 31: 391-408.

Behan-Pelletier V. M. 1999. Oribatid mite biodiversity in agroecosystems: role of bioindication. Agric. Ecosyst. Environ. 74: 411-423.

Berthet P., Gerard G. 1965. A statistical study of microdistribution of Oribatei (Acari) I. The distribution pattern. Oikos 16: 214-227.

Blakley J. K., Neher D. A., Spongberg A. L. 2002. Soil invertebrate and microbial communities and decomposition as indicators of polycyclic aromatic hydrocarbon contamination. Appl. Soil Ecol. 21: 71-88.

Haimi J. 2000. Decomposer animals and bioremediation of soils. Environ. Pollution 107: 233-238.

HANLON R. D., ANDERSON J. M. 1980. The influence of macroarthropod feeding activities on microflora in decomposing leaf litter. Soil Biol. Biochem. 12: 255-261.

KLIMEK A. 2013. Występowanie roztoczy (Acari) w bryłkach korzeniowych wybranych gatunków sadzonek w szkółce kontenerowej Bielawy [Occurrence of mites (Acari) in culture media of selected species of seedlings in the container nursery Bielawy]. Infrastructure and Ecology of Rural Areas 3/1: 115-124 (in Polish).

Klimek A., Chachaj B., Sas-Paszt L., Frąc M., Przybye M., Sumorok B., Treder W. 2014. Występowanie roztoczy (Acari) glebowych w ściółkowanej zrębkami uprawie truskawki [Soil mites (Acari) in the cultivation of strawberries mulched by wood chips]. Infrastructure and Ecology of Rural Areas II/3: 849-863 (in Polish).

KLimeK A., Kowalska A. 2013. Porównanie akarofauny (Acari) glebowej na gruntach porolnych i leśnych w początkowym etapie sukcesji leśnej [Forest comparison of soil mites (Acari) on 
post-arable land and land in the initial stage of forest succession]. Infrastructure and Ecology of Rural Areas 3/II: 47-57 (in Polish).

KlimeK A., PoкоRa J. 2009. Roztocze (Acari) glebowe upraw sosnowych i brzozowych na gruntach leśnych oraz porolnych na siedlisku boru świeżego w Borach Tucholskich [Soil mites (Acari) of Scots pine and birch cultivations on forest grounds and post-arable lands in Tuchola Forests]. In: Diagnozowanie stanu środowiska. Metody badawcze - prognozy. Kompleksowe badania i ochrona środowiska naturalnego (Garbacz J. ed.), pp. 95-103, BTN, Bydgoszcz (in Polish).

KlimeK A., Rolbiecki S. 2011. Wzrost sosny zwyczajnej (Pinus sylvestris L.) i występowanie roztoczy (Acari) glebowych na rekultywowanym terenie popoligonowym w Nadleśnictwie Żołędowo [Growth of Scots pine (Pinus sylvestris L.) and occurrence of soil mites (Acari) on the reclaimed post-military area at forest district Żołędowo]. Infrastructure and Ecology of Rural Areas 1: 249-262 (in Polish).

Klimek A., Rolbiecki S., DŁugosz J., Stypczyńska Z. 2009a. Roślinność, wybrane właściwości gleby i roztocze (Acari) we wstępnej fazie sukcesji leśnej na rekultywowanym terenie popoligonowym Bydgoszcz-Jachcice [Vegetation, chosen properties of soil and mites (Acari) in the introductory phase of forest succession on the reclaimed post-military area BydgoszczJachcice]. Infrastructure and Ecology of Rural Areas 5: 167-181 (in Polish).

Klimek A., Rolbiecki S., Rolbiecki R. 2013a. Effect of irrigation and organic fertilization on oribatid mites (Acari, Oribatida) in forest nursery. Sci. Res. Essays. 8: 227-237.

Klimek A., Rolbiecki S., Rolbiecki R., DŁugosz J. 2011. Wykorzystanie kompostowanego osadu ściekowego i ektopróchnicy leśnej do wzbogacania gleb w rocznym cyklu produkcji sadzonek sosny zwyczajnej [The use of composted sewage sludge and forest ectohumus for enrichment of soils in the one-year production cycle of Scots pine seedlings]. Infrastructure and Ecology of Rural Areas 1: 299-311.

Klimek A., Rolbiecki S., Rolbiecki R., Hilszczańska D., Malczyk P. 2008. Impact of chosen bare root nursery practices in Scots pine seedling quality and soil mites (Acari). Pol. J. Environ. Stud. 17: 247-255.

Klimek A., Rolbiecki S., Rolbiecki R., Hilszczańska D., Malczyk P. 2012. The effect of nursery measures on mycorrhizal colonisation of Scots pine and occurrence of soil mites. Sci. Res. Essays. 7: 2380-2389.

Klimek A., Rolbiecki S., Rolbiecki R., Kowalska A. 2013b. Porównanie wpływu ściółkowania ektopróchnicą i sterowanej mikoryzacji na rośliny oraz roztocze (Acari) w kontenerowej produkcji sadzonek sosny zwyczajnej [Comparison of the effects of mulching with ectohumus and controlled micorrhization on plants and mites (Acari) in the container production of Scots pine seedlings]. Infrastructure and Ecology of Rural Areas 3/I: 37-50.

Klimek A., Rolbiecki S., Rolbiecki R., Malczyk P. 2009b. Impact of chosen bare root nursery practices on white birch seedling quality and soil mites (Acari). Pol. J. Environ. Stud. 18: 1013-1020.

Klironomos, J. N., Kendrick, W. B. 1996. Palatability of microfungi to soil arthropods in relation to the functioning of arbuscular mycorrhizae. Biol. Fertil. Soils 21: 43-52.

Lehmitz R., Russell D., Hohberg K., Christian A. , Xylander W. E. R. 2011. Wind dispersal of oribatid mites as a mode of migration. Pedobiologia 54: 201-207.

Lehmitz R., Russell D., Hohberg K., Christian A. , Xylander W. E. R. 2012. Active dispersal of oribatid mites into young soils. Appl. Soil Ecol. 55: 10-19.

Lindberg N., Bengtsson J. 2005. Population responses of oribatid mites and collembolans after drought. Appl. Soil Ecol. 28: 163-174.

LusSENHOP J. 1992. Mechanisms of microarthropod-microbial interactions in soil. Adv. Ecol. Res. 23: $1-33$.

MazUR S., Tracz H. 1996. O znaczeniu i sposobach zoo- i fitomelioracji zalesianych gruntów porolnych [The importance and methods of zoo- and fito-land-reclamation of afforested former agricultural land]. Post. Techn. Leśn. 60: 26-31 (in Polish). 
Pollierer M. M., Langel R., Körner C., Maraun M., Scheu S. 2007. The underestimated importance of belowground carbon input for forest soil animal food webs. Ecol. Lett. 10: 729-736.

Remén C., Fransson P., Persson T. 2010. Population responses of oribatids and enchytraeids to ectomycorrhizal and saprotrophic fungi in plantesoil microcosms. Soil Biol. Biochem. 42: 978-985.

Renker C., Otto P., Schneider K., Zimdars B., Maraun M., Buscot F. 2005. Oribatid Mites as Potential Vectors for Soil Microfungi: Study of Mite-Associated Fungal Species. Microb. Ecol. 50: 518-528.

Rolbiecki S., Klimek A., Rolbiecki R., DŁugosz J., Musią M., Ryterska H. 2013. Badania nad wykorzystaniem kompostowanego osadu ściekowego i ektopróchnicy do wzbogacania gleb w rocznym cyklu produkcji sadzonek lipy drobnolistnej (Tilia cordata Mill.) [Study on the use of composed sewage sludge and forest ectohumus for enrichment of soils in the one-year production cycle of littleleaf linden (Tilia cordata Mill.) seedlings]. Acta Sci. Pol, Formatio Circumiectus 12: 113-122 (in Polish).

Rolbiecki S., KlimeK A., Rolbiecki R., Kuss M. 2009. Wstępne badania nad wpływem wybranych zabiegów ulepszających na wzrost jednorocznych siewek sosny zwyczajnej oraz występowanie roztoczy (Acari) glebowych w szkółce leśnej w warunkach nawodnień [Preliminary study on the influence of chosen revitalization measures on the growth parameters of one-year old Scots pine seedlings as well as on the occurrence of soil mites (Acari) in the forest nursery under irrigation]. Infrastructure and Ecology of Rural Areas 5: 155-166 (in Polish).

Rolbiecki S., Klimek A., Rolbiecki R., Kuss M., Fórmaniak A., Ryterska H. 2010a. Wstępne badania nad oddziaływaniem wybranych zabiegów rewitalizacyjnych na wzrost dwuletnich siewek sosny zwyczajnej oraz występowanie roztoczy (Acari) glebowych w szkółce leśnej Bielawy w Nadleśnictwie Dobrzejewice [Preliminary study on the effect of chosen revitalization measures on the growth parameters of two-year old Scots pine seedlings as well as on the occurrence of soil mites (Acari) in the forest nursery Bielawy of Dobrzejewice Forest Inspectorate]. Infrastructure and Ecology of Rural Areas 13: 51-62 (in Polish).

Rolbiecki S., Klimek A., Rolbiecki R., Kuss M., Fórmaniak A., Ryterska H. 2010b. Wzrost siewek ściółkowanej brzozy brodawkowatej i sosny zwyczajnej w warunkach nawodnień w szkółce leśnej Bielawy w Nadleśnictwie Dobrzejewice [Growth of seedlings of white birch and Scots pine under irrigation at forest nursery Bielawy, Forest District in Dobrzejewice]. In: Diagnozowanie stanu środowiska. Metody badawcze - prognozy. Prace Komisji Ekologii i Ochrony Środowiska Bydgoskiego Towarzystwa Naukowego (Garbacz J. ed.), pp. 237-246, BTN, Bydgoszcz (in Polish).

Rolbiecki S., Klimek A., Rolbiecki R., Kuss M., Fórmaniak A., Ryterska H. 2011. Wpływ ściółkowania ektopróchnicą na wzrost siewek brzozy brodawkowatej oraz na występowanie roztoczy glebowych w warunkach nawodnień w szkółce leśnej Bielawy [Effect of mulching with ectohumus on the growth of white birch seedlings in two-years production cycle and on the occurrence of soil mites (Acari) under irrigation at forest nursery Bielawy]. Ekologia i Technika XIX 2: 73-80 (in Polish).

Schneider K., Renker C., Maraun M. 2005. Oribatid mite (Acari, Oribatida) feeding on ectomycorrhizal fungi. Mycorrhiza 16: 67-72.

Setala H. 1995. Growth of birch and pine seedlings in relation to grazing by soil fauna on ectomycorrhizal fungi. Ecology 76: 1844-1851.

SzUJECKI A., 1996. Ekologiczne aspekty odtwarzania lasu na glebach porolnych [Ecological aspects of restoration of forest on post-agricultural soils]. Prace IBL series B, 27: 47-55 (in Polish).

Treder W., Klamkowski K., Krzewińska D., Tryngiel-Gać A. 2009. Najnowsze trendy w nawadnianiu upraw sadowniczych - prace badawcze związane z nawadnianiem roślin prowadzone w ISK w Skierniewicach [The latest trends in irrigation technology - research related to irrigation of fruit crops conducted at the Research Institute of Pomology and Floriculture in Skierniewice]. Infrastructure and Ecology of Rural Areas 6: 95-107 (in Polish).

Wallwork J. A. 1983. Oribatids in forest ecosystems. Ann. Rev. Entomol. 28: 109-130. 
WANNER M., Dunger W. 2002. Primary immigration and succession of soil organisms on reclaimed opencast coal mining areas in eastern Germany. Eur. J. Soil Biol. 38: 137-143. 